\title{
Research Study on Centralized E-Learning Architecture Model for Educational Institutes in INDIA: Teaching \& Learning Process
}

\author{
M.R.M. VeeraManickam ${ }^{1}$ and Dr.M. Mohanapriya ${ }^{2}$ \\ ${ }^{1}$ Karpagam University (PhD Scholar, Dept. of CSE), Coimbatore, INDIA. \\ ${ }^{2}$ Professor \& Head, Dept of CSE, Karpagam University, Coimbatore, INDIA.
}

\begin{abstract}
Educational system in India demands a new technology in teaching and learning system at school and college levels. This paper would be beneficial to bring attention to the educational governing body in India to the pressing need of changing to teach \& learning activities with an elearning system as per modern technology. And further it focuses on importance of e-learning system \& need of infrastructure to be deployed in educational institute to felicitate for efficiency and efficacy of teaching and learning process. By Analyzing E-learning model for finding way to overcome the disadvantages of the Indian Educational Sector that lags in deploying the centralized e-learning models. Improving in usage of efficient proposed models approaches to overcome existing Decentralized model and need of centralized system features.
\end{abstract}

Keywords: E-Learning, Indian Educational Sector, E-Learning Architecture.

\section{Introduction}

E-learning is an on-line technology available at less cost and at no time for sending and receiving materials to share data notes for education. It is a mass on-line platform to utilize in Educational sector. A computer, a mobile hand set and tablet is the tool required for imparting e-learning materials. It is devices that indirectly help

Conservation of greenery by replacing paper and eliminating the cost. This system is implemented in schools, to improve quality and quantity of education. E learning allows everyone to learn easily without any issues.

"Three Features said for E-Learning on basis using online technologies for executing teaching and learning systems as:

- Online,

- blended learning and

- use of online as additional to face to- face for learning activities."1

Internet facilities are availed of by using the computer or the mobile. Comparing their usage, the mobile users outnumber the computer users for obvious reasons. Public Mobile penetrations being in higher range than computer, e-learning application can be made available in dual formats: mobile \& PC format.

\section{Existing System}

\subsection{Objective}

Few universities and colleges are using their independents e-learning systems. All system works on their method of functioning. Some institutes using Moodle system in their e-learning but not in line with another Moodle system. Hence all model not coordinated each other which lack in sharing their data each other. As results students using e-learning on their campus isolated from other e-learning system. This describes in detail e-learning services available in India.

\subsection{List of E-learning Services are listed below: Independent Structure}

\author{
A. UGC-Infonet 2.0 \\ B. NIELIT \\ C: NPTEL-National Program on Technology Enhanced \\ Learning \\ D: DEF-Digital Empowerment Foundation \\ E.ClassTEacher \\ F.Tata Interactive Systems \\ G. CommLab \\ H.ExcelSoft \\ I. LIQVID
}

\subsection{Users: E-learning System}

Corresponding author: manic.veera@gmail.com ${ }^{1}$, mohanapriyaasaithambi@gmail.com² 
In Campus level e-learning system regular under graduate and post graduate students are users. Nptel elearning system allows everyone to share and use their video lectures in this level everyone can be users who can able access nptel web link. In private service providers e-learning are totally payable services so anybody can be user after paying for their services. Any institute can get those payable services to use in their campus.

\subsection{Cost Model}

Moodle open source LMS: Is freeware software platform services. So anyone can deploy it by using proper infrastructure and network.

Governments NIELIT, NPTEL, DEF: Also freeware services provided to all which can be accessed by anyone.

Tata Interactive System \& other private services: are package based system can be used those who are deploying in their network

\section{Disadvantage}

There is no common platform among all types of users and institutes to use e-learning system which can be collaborated together. Significance of proposed system is to overcome issues like independent model, package system of cost, to make everyone involvements as stakeholders...etc

\subsection{Simple Survey on need of E-learning common Application}

Data collection on basis of sample data collected from group of students. Survey completed to get know real outcomes \& importance of e-learning among engineering college students. Data collected using shared Google documents with set of 10 questions. To get know students real interest and approach towards elearning to know its importance and need on their studies. Around 220 responses received from different discipline in engineering colleges. It's very simple survey to get idea about student interest on using elearning among group of students

\begin{tabular}{|c|c|c|c|}
\hline \multicolumn{4}{|c|}{ Data Collected among Engineering College Students } \\
\hline $\begin{array}{l}\text { Smart Phone } \\
\text { User (Yes/No) }\end{array}$ & Internet User $(\mathbf{Y} / \mathbf{N})$ & $\begin{array}{l}\text { Any E-learning } \\
\text { applications } \\
\text { currently in use? }\end{array}$ & $\begin{array}{l}\text { Are you members } \\
\text { of any Social } \\
\text { Websites }(Y / N)\end{array}$ \\
\hline $54 \%$ & $82 \%$ & $18 \%$ & $80 \%$ \\
\hline $\begin{array}{l}\text { Do you like to } \\
\text { use any e- } \\
\text { learning Apps. } \\
\text { for learning } \\
\text { subjects }\end{array}$ & $\begin{array}{l}\text { Do you like to Share } \\
\text { subjects notes to } \\
\text { others thru- mobile } \\
\text { application }\end{array}$ & $\begin{array}{l}\text { Do you think college } \\
\text { administartion } \\
\text { should take } \\
\text { intiatives to delevop } \\
\text { E-learning Apps. }\end{array}$ & $\begin{array}{l}\text { Goverment } \\
\text { administartion also } \\
\text { can take intiatives } \\
\text { to delevop new E- } \\
\text { learning Apps. }\end{array}$ \\
\hline $78 \%$ & $90 \%$ & $70 \%$ & $78 \%$ \\
\hline
\end{tabular}

Table -1 Simple Survey on E-learning Importance among Engineering Students

\section{Research Questions: primitive for the need of centralized e-learning system in India.}

We have to find a solution to the following research questions? I have proposed three models altogether focus on need of centralized e-learning system in India for teaching as well as learning activities. I have analyzed and found some basic suitable architecture on the basis research question to this specific problem like need of 1) centralized e-learning system, 2) importance of Data Center, 3) Role of every educational institute, 4) Government's Policy, 5) role of Indian Information technology industry to help governments

The Five basic things are considered to compile these research questions

\section{What is the need of centralized e-learning system?}

2. What is the scenario of existing system?

3. Is there any government policy for implementing common e-learning model?

4. What is the role of educational institutes in developing a common system?

5. Is there any contribution from private sector \& educationalist to improve and build needed infrastructure for e-learning model

6. Is there any standard common e-learning application for student's mobile user in India?

7. What is the role of IIT's to bring common e-learning system in institute's level.

\section{PROPOSED MODEL: Centralized E- Learning Architecture}

All existing e-learning system lacks in centralized model and independent each other. No common platform and infrastructure to make use of e-learning system efficiently in term of sharing, developing econtent, role and involvement of all stake holders. Proposed system on basis of Architecture of Centralized E-learning system, Importance of Data Center and Cloud usage, Cost prediction of Data Center, Implementation phases of E-learning application development, Project cost contribution of stake holder and their role, Role of IIT's to develop new data centres, Role of other universities and college on contributing in developments of data centre and e-learning application.

"An averagely Indian using almost 5 hours in internet out of that 3 hours is spent on mobile device internet, only 45 minutes are used by doing any other works apart from social media." 3 Maximum Indian using just 45 minutes time in online for other activities than social networks. This scenarios has to be changed from 45 
minutes to more time usage especially for students, the perspective time spent for internet can be improved by giving availability of courses thorough e-learning for more than hour per day. Basic purpose is to increases online time spent in front of system to student's community. "Schneckenberg (2010) emphasized that communities of practice social and peer collection networks have an impact on the student involvement in eLearning."

"Technologies used to enhance content quality of courses are given in system. Opportunity to engage user games based learning is also provided in the system. It excites everyone to learn efficiently that they can immerse in learn knowledge through Games and thereby learn through their own mistakes.",

Government should initiate all possibility of building data centre's that will eliminate barriers for nonavailability centralized e-learning system in India. "Panda and Mishra observed that increase of motivating aspects was important for achievement of an eLearning initiative as removal of the possible obstacles."

\subsection{E-learning Effective System}

Effectiveness based on time, hard work, quality content, courses curriculum has to be implemented in e-learning system.

"E-learning supports the Organization's objective, improved schooling costs, decreased material costs, increased output, Standardization.",6

Subject material content.

All learning styles to be deployed.

"In compiling these elements of effective design, It is because of this amplification of technological tendencies that the design phase is so critical. These six elements activity, scenario, feedback, delivery, context, and influence - provide focal point for the educational designer, support in the navigation of the intricacy and the often conflicting pressures that weight the development of an effective e-learning design."7 Easy way of understanding e-learning system.

Cost Effective

"3 points influences in favour of e-learning: It is really cost effective, it can adapt lessons and allow self-pacing to produce a more personalized learning experience, and it can gain access to countless users at their individual suitability via the Internet.",

Easy to navigate all functional system features.

Course should be available to every student in system.

"One of the impressions of the credit critical point has been a renewed look at the probable of e-learning.

Lower costs, high speed of delivery, more effective learning, Lower ecofriendly impact"9
Good communication system between learner and instructor.

"E-learning supports the using learner Progress in many ways likes Real-time

Access, Liberty to fail, improved retaining, personalized learning."6

\subsection{E-LEARNING ARCHITECTURE MODEL}

Architecture Models are proposed to describe importance of e-learning on basis of Infrastructure, Data Center Cloud usage, Zone wise Connectivity, Role of Indian Institute Technology IIT's in New Data Center, Role of Colleges and Universities too.

1) Centralized E-Learning Infrastructure \& System Connectivity Model

2) Centralized E-Learning Architecture Model

\section{Architecture of Centralized E- Learning Infrastructure \& System Connectivity Model}

\subsection{Design and Delivery of eLearning by Coordination activities}

The launching of an e-Learning system by clubbing together all four networks will be a well-coordinated team effort, and domain experts as diverse departments are involved in the deploying system. The phase by phase methodology to enlargement and launching of eLearning system helps institutes to work on different activities in an effective and efficient manner.

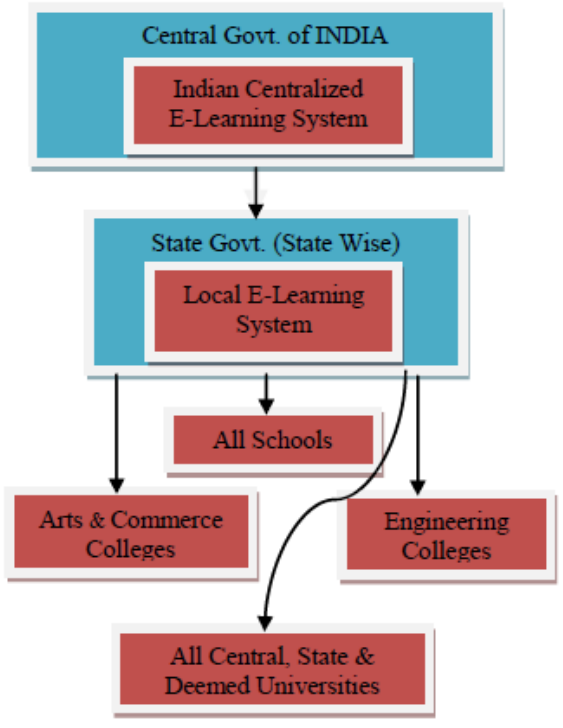

Figure 1 Proposed Centralized E-Learning Infrastructure \& System Connectivity Model

Educational institutes can utilize their own 
infrastructure. So students and instructor can interact with each other using a common platform of E-learning System.

Network 1 to club all Schools together under single Elearning system

Network 2 to club all arts and Commerce College under single E-learning system.

Network 3 to club all Engineering college under single E-learning system.

Network 4 to club all university under single E-learning system.

All four e-learning system networks can be connected together to same centralized system. Monitoring committee can have member from all four networks to govern activities of the e-learning system. "It was exposed that $31.7 \%$ of the organization have advisory body to observe the quality of eLearning."1

\section{Architecture Of Centralized E-Learning Model}

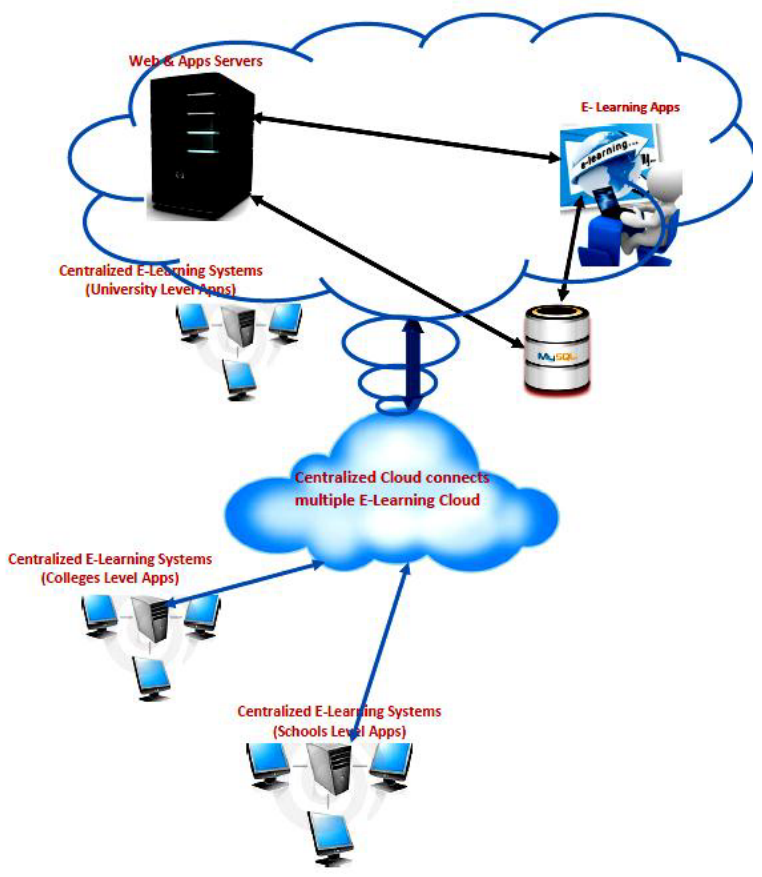

Figure 2 Centralized E-Learning Architecture Model

The architecture focuses on creating a small cloud elearning system to group the similar sets of institutes like Universities, Colleges \& schools, to bring a common platform for sharing their academics related data, notes...etc. So learning and teaching processes can be made effective and speedy. The productivity of the communicating media is also increased by inculcating multiple networks in to a single system. Reason behind in usage of cloud is easy way to create network model connectivity between $\mathrm{n}$ numbers of user using www instead of standalone C-S model. In case of C-S model we need to make network connectivity among every member networks and user. Using www is another big advantage to handle easy updates, sharing of data resources, providing synchronized communication between $n$ numbers of parties.

Nowadays, there is no such common platform existing anywhere in India. The sooner the system is put in place; better benefits would be felt at schools, colleges and universities by connecting $\mathrm{pc}$ in to multiple networks. And, governments from the centre and the states can promote this type of platform connectivity by allocating funds to create an infrastructure of public private partnership for such workstation like centralized cloud e-learning system. Indian IT industry partnership can be sought to deploy and maintain such huge centralized system that may face typical challenges. "Challenges for execution of eLearning programmes include: Deficiency of suitable training for those involved with eLearning (41.5\%), Commercial Constraints $(40.2 \%)$, Inadequate programme development services (39\%), Non-tech-savvy individuals $(37.8 \%)^{\prime \prime 1}$

\subsection{USERS: CENTRALIZED E-LEARNING SYSTEM}

Every Student can be member of this system like social networking concepts. Connectivity models system and their access permissions. Just like sharing on public, only in circles network or on basis of campus network alone.

"Freely Usable Educational Information System Architecture study intended to lead students to access and share various educational information more easily"

${ }^{10}$ Purpose of notes sharing among student community increasing day by day by using efficacy e-learning technologies

Students Users Connectivity

1) IIT's, Universities \& Colleges Campus Network members

2) Any Non members outside Network Students Sharing Connectivity

1) Sharing among Campus network members

2) Sharing to non members

3) Sharing through Payable access to both members and non members

"Mobile learning is up-and-coming and transmuting the outdated educational style way. It leads new learning environs due to the rise of mobile and wireless technologies." 11 Mobile user increasing tremendously among students learners so it's important to make use of technology for attract maximum number of user for our e-learning model

\section{CONCLUSION}

E-learning is a technology advanced system of education for multitier advantages and it is a sad affair that most of the educational institutes in India lack any facilities to implement it as independent or centralized system. Institutes have to take initiative, government have to support them and know how companies have to 
lend all kinds of support for implementation of this centralized system for a spectacular improvement in quality of teaching system for education, which in turn produce more knowledgeable candidates with better employability now far low. The education system in India will be a manifold effective model of centralized e-learning system using data centre's infrastructure for purposes of sharing data among institutes with smart simplified mobile application

\section{References}

1. "ELearning in Commonwealth Asia 2013" by S.K. Pulist, ISBN: 81-88770-12-4 (10 digits), Copyright (C) CEMCA, 2013, available online http://www.cemca.org.in. Date accessed: 05/03/2016.

2. "A Study on Educational Games Application Model in E-Learning Cloud System" by Mr.Veeramanickam, Dr. N.Radhika from ICICES IEEE conference on 27th \& 28th Feb. 2014.

3. "Mobile And Internet In India 2014: 349 Million Unique Mobile Phone Users, 70\% Traffic From Mobile" By Bhavya Srivastava on July 11, 2014, http://dazeinfo.com/2014/07/11/mobile-internetindia-2014-349-million-unique-mobile-phone-users70-traffic-mobile-india-shining-infographic. Date accessed: 05/03/2016.

4. Schneckenberg, D. (2010). "Overcoming barriers for e-learning in universities - Portfolio Models for ecompetence development of faculty", British Journal of Educational Technology, 41(6), 979-991. doi:10.1111/j.1467-8535.2009.01046.x

5. Panda, S., \& Mishra, S. (2007). "E-learning in a mega open university: Faculty attitude, barriers and motivators", in Educational Media International, 44(4), 323-338.

6. Data retrieved from "The Rapid E-learning Blog Why ELearning is So Effective February 2nd, 2010, http://blogs.articulate.com/rapidelearning/whyelearni ngissoeffective.".Date accessed: 05/03/2016.

7.http://www.irrodl.org/index.php/irrodl/article/view/217/ 300 Elements of Effective eLearning Design, by Andrew R. Brown \& Bradley D. Voltz. .Date accessed: 05/03/2016.

8.http://www.strengtheningnonprofits.org/resources/elear ni ng/ online/effectiveelearning - "Effective Elearning" .Date accessed: 05/03/2016.

9. http://www.kineo.com/resources/newtoelearning/

thebenefitsofelearning titled "The Benefits of E-learning | When should you use it?." .Date accessed: 05/03/2016.

10. Junghoon Kim ,"Analysis of Requirements for Implementation of a Freely Usable Educational Information System Architecture", Indian Journal of Science and Technology,2015 Apr, 8(S8), Doi no:10.17485/ijst/2015/v8iS8/70513

11. Dae Hyun Lee, Jin Gon Shon, Yong Kim, "Design and Implementation of OSMD Based Learning Management System for Mobile Learning”,Indian
Journal of Science and Technology,2015 Jan, 8(S1), Doi no: $10.17485 / \mathrm{ijst} / 2015 / \mathrm{v} 8 \mathrm{iS} 1 / 57891$ 